\title{
Using Films in Vocabulary Teaching of Turkish as a Foreign Language
}

\author{
Adem İşcan \\ Correspondence: Adem İşcan, Faculty of Education, Gaziosmanpaşa University, Taşlıçiftlik Campus, 60150 Tokat, \\ Turkey.
}

Received: February 27, 2017

Accepted: March 23, 2017

Online Published: March 26, 2017

doi:10.11114/jets.v5i5.2245

URL: https://doi.org/10.11114/jets.v5i5.2245

\begin{abstract}
The use and utility of auditory and visual tools in language teaching is a common practice. Films constitute one of the tools. It has been found that using films in language teaching is also effective in the development of vocabulary of foreign language learners. The literature review reveals that while films are used in foreign language teaching and there are many studies in this subject, very few studies have been done in our country and this is not enough. In this study, the development of Turkish vocabulary of foreign students through films has been discussed. Examples of activities aimed at the development of reading skills through films that teachers can use in foreign language are presented.
\end{abstract}

Keywords: word, foreign language, Turkish

\section{Introduction}

In Turkish Dictionary, the 'word' is defined as a sound or sound cooperation with meanings (TLA, 2005). Korkmaz makes a more detailed description by taking the word concept in both form and meaning. For him, the word is "the language unit which consists of one or more phrases of plural syllables, which relate to abstract or concrete and abstract concepts that reflect concrete or certain emotions or thoughts corresponding to a certain conception when used alone in the mind among speakers of the same language" (Korkmaz, 1992). Lewis, on the other hand, defines the word as the linguistic heart.

Students' senses of what they read, what they listen to depending their correct meaning of the words. It is natural for individuals with rich vocabulary to use their reading, listening, speaking and writing skills more effectively (Karatay, 2007).

Wilkins (1972), empahises the importance of word knowledge by saying '"you can communicate on a language without grammer, but you can not communicate without a word knowledge'.

The development of the vocabulary of foreign language students leads to the development of other basic language skills as well. For that reason, it is very important to improve the vocabulary of students in foreign language teaching.

\section{Method}

The research is structured with a qualitative approach. Descriptive analysis was done while interpreting the data obtained in the study. The result was reached with the information gathered from the literature.

\section{Theoretical Framework}

\subsection{Teaching Turkish Words as a Foreign Language}

The basic element of language learning skills is words. New words learned at each level are produced and understood as meaningful whole by being assembled with learned language grammar rules. Development of the word is also a condition that improves the ability to express (Yıldiz, 2013).

The most difficult topic for students learning Turkish as a foreign language is vocabulary learning. Teachers cannot use the necessary materials for word teaching due to material and time problems. Students find it difficult to keep words in mind, particularly in words that meet abstract beings. It can be argued that this problem is caused by the fact that students are made memorize instead of using different methods and techniques to make it easier to remember and to be permanent (Kana \& Keskin, 2014).

The following activities can be done for the development of the vocabulary of students in teaching Turkish as a foreign language (Demirel, 2007): 
1. Real objects or examples are presented.

2. The meaning of the word, which is taught, is explained by gestures and mimics.

3. Visual tools are used.

a) Magazines, newspaper pictures, wall paintings, flash cards, posters, banners are used.

b) Shapes, sketches, pictures or line drawings are drawn on the wood.

c) Film strips, figures, dialers (slides) or overhead transparencies are used.

4. Explanation is made on target language. For this;

a) The meaning of new words is explained using previously taught words.

b) The synonyms and antonyms of the words are presented.

c) The words transferred to mother language from the foreign language are presented. For instance; radio.

d) With the help of the first and the last suffixes, the meaning of the new word is related to what was learned before.

5. Dictionary provisions are found.

6. They are asked to guess the meaning of the words, or extract them from a text they have read or heard.

7. If none of the above listed options are appropriate, the meanings in the main language can be presented.

\subsection{Use of Films in Teaching Foreign Language Vocabulary}

As in other language teaching areas, various attitudes and methods have emerged in teaching words in recent years, too. According to Celce-Murcia and Rosensweig (1979), the method of grammar translation emphasizes the recognition of written words and the awareness of each word used in speech and the importance of inflections. In addition all languages have been worked similar to Latin. However, since the primary objective of the reading approach is a complete understanding of written material on the foreign language, it is more concerned with the understanding of the word. Both approaches focus on looking at the dictionary when necessary or translating texts from foreign languages and both approaches do not focus on complete language comprehension or speaking skills of the students.

Thus, the other two approaches, the Auditory-Linguistic method and the Direct Method, has emerged in response to the former ones. Direct method suggests that an individual learns a foreign language in an active and meaningful context and that the individual only uses and hears the target language in the class. The role of the word is very important and it is learned as an integral part of every language.

On the other hand, the Auditory-Linguistic Method deliberately placed very little emphasis on vocabulary teaching in the first stages, keeping the basic structures and language system at a very low level until fully understood. When assessed as a whole, word teaching in recent years has secondary importance. However, nowadays, the role of vocabulary is important and teachers try to balance in all other areas of language learning (Ruusunen, 2011).

Until recent years, vocabulary teaching has always had secondary importance in language teaching. But now vocabulary teaching is very important and educators are focusing on the relationship in different areas of language teaching. It is very important that the teacher is aware of the importance of teaching vocabulary in language teaching. If the teacher does not think that vocabulary is very important in language teaching, he/she will not pay enough attention to it. Today's trend, however, focuses on communication and interaction on the foreign language. Thus, in addition to linguistic knowledge and other verbal skills, the field of vocabulary is also remarkable. According to Nation (1990) learners feel that inadequacy in vocabulary resulted in their difficulties in both receptive and productive language use.

Celce-Murcia and Rosensweig (1979) emphasize the difference between active word processing (recall and production) and passive word processing (recognition and understanding). The teacher should know in which category the word collection is. The uses of active word combinations in lessons are very important. Besides, the use of passive words in teaching listening and reading may decrease the efficiency of the course. Another important point is that the teacher decides whether to teach passive vocabulary constantly or temporarily, so that the learner can understand a text or a film. However, both passive and active vocabulary is essential in teaching foreign languages. Learning new words on a foreign language is not always easy. It requires too much repetition and practice (Ilgizovna, 2015)

Yüksel and Tanriverdi (2009) focus on the benefits of using the subtitles while watching movies. Subtitles improve the learning of words as they allow the language learners to see the word in context. In addition, movies, for example, helps learning some words more easily through themes.

Movies motivate students not only to learn the target vocabulary but also to understand the target language better. 
According to King (2002), films offer more educational options to students and they have a rich content to motivate them. When students watch the movie-usually subtitled films-learn some words and phrases related to the target language. They also learn how to pronounce a lot of words through movies, too.

Vocabulary is important in foreign language teaching. Because, in the communication process, it assumes a carrier role to convey the information or thoughts and the message which is given. Therefore, the inadequacy of vocabulary knowledge in foreign language teaching will cause inadequacy in communication of the target language. The student cannot understand the target message effectively without having knowledge of the word. In addition, vocabulary knowledge is important because it supports the other four basic skills of language (speaking, listening, reading, writing). Students have many problems with vocabulary when they read books. Many students have difficulty in understanding the meaning of the words and memorizing them. The second problem is that the words are similar to each other in sound, and they have difficulty in distinguishing them. Students are generally confused about this subject. Another problem is that how words are used in the sentences. This leads to their lack of self-confidence.

Films are one of the audiovisual tools that can be used in teaching foreign languages. A film can be seen as a means of communication between teachers and students. Through the film, students can easily handle the problems they have in the target language. Through the film, students will participate more effectively, actively and enjoyably (Harmer, 2001).

It may be more useful to watch some part of the film in word teaching. Teachers can benefit from the story of the film when creating a vocabulary list. While the students are talking about the new words they see in the film, the teacher can make students do activities for speaking at this stage. They can tell the story of the film. After watching the movie, they can summarize the film simply with the new words they have learned.

Movies undertake the task of conveying the meaning of words through contexts. Context is an important framework for embodying the meaning of the word. The presenting the meaning of a word in a film is easier than it is read and understood from the book or any text. Students have a number of difficulties learning target words. Students do not only have any difficulty in knowing the meaning of words alone. They also have difficulty in correct pronunciation of the word. Moreover, the students may forget the meaning of the word after a while. The meaning of words can be learned through a dictionary. But after a while, students may forget that meaning again. There are many ways of teaching vocabulary on foreign languages. But interaction in class is very important. Many students do not engage in learning vocabulary in the class and this is a serious problem. In this process, however, the student must deal with this issue seriously and must actively participate in it.

Scenes in the film will be much more effective in language learning if they are carefully selected for training purposes. The scenes must also match the age and level of interest of the students. Otherwise, there will be lack of attention in the student. Subtitles should also be clear and understandable. The words that are important in the film should be under lighted in a colorful way. It is also important that the voice in the film must be on and clear so that students can pronounce the words correctly. Worksheets (should contain important words, examples and pictures related to the film) are also important for the students to watch the films in accordance with the educational purposes of them.

Word teaching is a part of teaching a language with a film. This allows the students to discuss on the film, thanks to the new words they learn in the target language. There are some issues that the teachers must take into consideration while practising this subject. Teachers should first consider possible problems (such as swearword, slang, or pronunciation problems) related to the level of students, the purpose of the course, and the vocabulary of the film. Materials related to film vocabulary should be organized. Many sources for film (such as power point presentations, worksheets and interactive websites) can be found. Test materials can also be prepared to assess students' works and control them. (http://www.eslteachersboard.com/cgi-bin/lessons/index.pl?read=4295)

Many researchers have pointed out that subtitle films are more effective in teaching vocabulary in foreign language teaching through films.

The use of subtitled films in language teaching helps students develop reading, listening and comprehension skills as well as new vocabulary learning. By watching the subtitled movies, students get knowledge about different and special usage areas of the language. In addition to word meaning, they learn how to use these words in many cases. In addition, they will develop the skills of distinguishing some different words on target list, word pronunciation and correct sentence structures. Koolstra and Beentjes (1999) claim that a high level of learning in vocabulary teaching is achieved with subtitle films or watching the films more than once can be more effective in vocabulary teaching. It can be taught that if the film is watched twice or several times, it will be more effective for the students in learning the new words, phrases and statements (As cited in Putra, 2014).

While watching movies is a helpful fact in language teaching, it can sometimes be difficult for students to understand the film. Thus, as an educational tool, the substitles plays a vital role in understanding the film. According to Esseberger, 
educational films can be used in many ways as an audiovisual aid tool. They can be shown to foreign language learners with subtitles or without subtitles. Subtitled films, however, allow students to see all the words, which are in the conversations in the film, in concrete terms. Also with the help of film details and additional information, they will have a better understanding of the film (Harji, Woods \& Alavi, 2010).

Discussions are also being made about the ways in which subtitled films can be used to learn language. The films can be viewed with two-way subtitles that can be controlled or uncontrolled. That is, dialogues on the target language can be viewed with repeated or unrepeated subtitles. Perhaps the students will be happy to watch the films with the subtitles (voice and text together) that can be controlled. Because, they will see the words several times during the watching and find opportunities to reinforce them. The use of films according to Zarei (2009)-especially the use of subtitling films-is one of the most enjoyable and comfortable methods of teaching target language vocabulary. According to some scientists (Paivio, 1971, Stewart \& Pertusa, 2004), subtitle film monitoring - along with new word and word content in its content-helps foreign language learners develop their target language skills as they have a rich target language target content.

Bird and Williams (2002) used subtitles as one-way (voice or text) and two-way (voice and text) in studying the effects of subtitles in word teaching and eventually found that the use of subtitles was effective in learning the words in the story (Shirazi, Account \& Simin, 2016). Similarly, in the Shirazi's, Accident's and Simin's study (2016), it was shown that students who watched a subtitle film learned the vocabulary of the target language more easily and that the students had an effective learning environment thanks to their interaction with each other.

\subsection{Vocabulary Activities Related to Films That Can Be Used in Foreign Language Teaching}

In this part, in some researches related to the topic, the examples of activities suggested by the authors will be presented.

A number of different activities can be organized on the use of films to improve foreign language vocabulary teaching. Here the teacher plays a key role. A scene or section is taken from a movie (including house sale, house purchase, or home visit). The entire words related to this scene or section is removed and a list is made. As a preliminary activity, students are asked to prepare their home advertisements in pairs or in groups (to identify their home). They can prepare these preparations for the school magazine or newspaper. Once the scene is watched, the class discusses its content and students try to remember all the words and phrases they hear about the home story. The words and phrases that the students say are written on the board. Teacher warns students that they should be more careful in the second watching. Later, the students write about all the words and phrases they hear which are related to home conversation. After the second watching, the students complete the word list on the board. As an after-watching activity, they are asked to animate the scene on stage using the words they know about the house conversation. They are asked to write a related essay as a homework (Talaván, 2007).

These activities which are prepared for teaching vocabulary through the films in foreign language are a preliminary preparation for vocabulary teaching in written texts as well as improving the vocabulary of students.

\section{Visual details and space related activities}

1) The use of film enables a picture to be formed in the minds of the place where the events pass before the students read the story or the novel.

They also learn the key words they will need to understand the story. The following guidelines can be followed for this event:

A) Divide the students into groups of two. Only one of the two students e.g. student A will see the screen.

B) Show a silent scene or a still picture. Let student A make predictions about student B's sightings.

C) Then does the opposite. So they talk to each other about what they see on the screen.

D) Ask them to refer to the dictionary of new words they see on the screen. Because they may need it. They will also see the correct pronunciation of the words.

E) Ask them to write a short essay about the picture or scene - using the words they learned - as homework.

2) Select a scene from the movie (where an object or place is shown) and pause the movie. Put some sticky paper on top of the screen. Ask students what you think about this still picture. Gradually animate the picture. Prepare a vocabulary list so that students can describe the picture.

3) A student can only look at the screen. Turn the screen so that it is not visible to other students. Stop the movie or show a scene with the sound closed. Class, ask students questions about what are in the picture.

4) Divide the screen: use a large piece of cardboard or a moving writing pad for it and position it at the correct angle on the 
screen. So half of the class will see one half of the screen, the other half. Students will ask each other questions about the parts they do not see on the screen, so they will ask each other questions.

\section{Events related to character analysis}

1. Prepare a list of words and phrases from the master or other sources (such as web sites) that contain the characteristics, physical attributes, and important aspects of the movie.

2. Select a scene where five or six characters are fully displayed. Turn the screen away from the class and turn off the sound. Allow individuals to monitor a small part of the scene by turning the screen towards the students. Each student follows this piece and depicts each character on the screen for the class. The class tries to decide who the character is and how many.

3. A section of events is displayed (Up to 10 minutes). At the same time as they watch it, they prepare a list of characters. So they think of words that define characters in groups. Thus, the students want to know whether the word choices are correct by remembering the events on the film. At the end, the teacher checks with the student whether the word choices are correct.

(http://www.ucnorth.dk/Files/Filer/CFU/Fagene/engelsk/Penguin_Readers_Teachers_Guide_Film_TV.PDF)

Before watching the movie, you can take a look at the word list on the film and try to guess the film in topic. You may also be asked to portray the main character of the film by looking at his picture. While watching the movie, you can make a gap filling exercise with the film summary by means of the given word list. However, it may be desirable to close the volume and guess the dialogue of a part of the scene in the film. After watching the film, they are also asked to fill in the gaps in the sentences concerning the interpretation of the film. As homework, they are asked to write their own comments about the film (6-8 sentences) (Ilgizovna, 2015).

Rajasekaran (2015) prepared a lesson plan and an activity example to be used in the teaching of vocabulary through films:

Event type: Individual event

The purpose of your activity: to improve the vocabulary of the students with films.

Level: Intermediate level

Source: A copy of the film

Teacher's task: Feedback on previous events.

The task of the learner: Watching movies and taking notes.

Location: Classroom or Seminar/Conference room.

Practice and Instruction: For easy understanding of the film, the teacher makes a summary of the film. The film is watched as subtitles and then without subtitles. After the film screening, students are asked the following questions:

1. What is the film's motto?

2. Discuss the film's quality.

3. Discuss the message in the movie.

4. What do you think about the female characters in the film?

5. Was the end of the film as you expected?

6. Think about an alternative end to the movie.

Observation: Students enjoy watching long-time movies in language classes. They do not have trouble watching the movie. Because all the talk in the film is the level they can understand. The dialogue is clear and understandable, and the lack of mixed dialects makes it easy to understand. So they will want to watch more movies in language classes. Students will write many words in the film and thus answer all questions about the film. But since the students each have different perspectives, the answers they will give to the questions will be different.

\subsection{Selection of Films in Teaching Turkish as a Foreign Language}

The choice of movies to be watched by students in teaching Turkish with foreigners is extremely important. The most important responsibility in this regard falls to the teachers. The main points to note when choosing movies are:

1. Firstly, the Turkish film to be selected should be suitable for the language level of the student and for educational purposes.

2. Watching movies with or without subtitles should be preferred according to the level of students. For example, subtitle films for students at A1 and A2 level, and without subtitle films for students at B1 and above level students. 
This will make the films easier to understand and one step closer to the student's achievement of the target achievements.

3. The content of the film should be checked in advance and should not contain sexual or violent elements.

4. The length of the activity to be done with the video film is at most half the time of one lesson; If we accept a lesson for 40 minutes, it should be 20 minutes. The total number of activities to be done depending on the video movie should be 20 minutes. The length of the video film that will be used in the video film lesson should be at most ten minutes in this case (Taşdemir, Bilkan \& Can, 2004: 9)

5. Video films to be watched should be planned according to the students' interests, cultures, lifestyles and beliefs. Interesting video films will affect the lesson positively (Arslan \& Adem, 2010).

6. Film in theme should not be complicated.

7. The teacher should prepare pre-film, film sequence and post-film activities. Without Film in, only Film in will not be able to succeed on this issue. Without events only watching the film will not lead us to success on this issue.

8. The Turkish in the film should reflect all the features of the daily spoken language. Care should be taken that slang and idioms do not take place too much. Because of the special use of Turkish taking too much place in the film will cause confusion in the student.

9. The characteristics of the mouth of the Turkish should not be too much in speaking of the characters. Otherwise students may have difficulty in understanding the film.

10. The Turkish films to be selected should be directed towards the development of different teaching and skill areas (such as speaking, writing, reading, listening, linguistic knowledge, vocabulary teaching and cultural teaching) in terms of form and content.

\subsection{Vocabulary Activities Related to Films That Can Be Used in Teaching Turkish as a Foreign Language}

\subsubsection{Hababam Class (1975)}

\section{Appropriateness of using the film as a foreign language for teaching Turkish}

The film is the first among the best Turkish films with 9.5 points in IMDB (Internet Movie Database) site. In the Hababam Class, the Turkish education system has been approached critically and humorously. Three things are criticized in the Hababam Class: the copy, the memorization and the respect of the fabric. This film, which describes the educational system as a humorous language, is considered to be one of the auxiliary course materials that can be used in teaching Turkish as a foreign language.

\section{The Theme}

Mahmut Hoca (the other name Kel Mahmut), who is the newly appointed director and history teacher of Private Çamlica High School; tries to discipline by means of interesting punishment methods the classroom of 6 Literature B (the other name Hababam Class) which is full of students who make copies, run away from school, go to matches. But at the same time, there are serious incidents other than the disgust of the students. (https://www.turkcebilgi.com/hababam_s\%C4\%B1n\%C4\%B1f\%C4\%B1_(film)).

Players

Kemal Sunal, Münir Özkul, Halit Akçatepe, Tarık Akan, Adile Naşit, Şener Sen

Activity of teaching a word related to Hababam Class movie

The Name of the Activity: Activity of finding appropriate words

Instruction: A two minute scene is shown from the movie. The teacher gives the students a work paper which consists of the statements previously in the dialogues in the scene. The study paper should include a list of words left blank in the first place. The place left empty in the rumors should not be more than a word. At the end of the activity, students' answers are evaluated together with the class.

Application:

Scenes to be watched: 15-17. Minutes

Worksheet

Words: Aged, break, slap, me, contemporary, elementary school, letting down, lesson, school, we, pour

Sentences:

This is our first lesson if you want a bit of each other ..) 
(...........) we call him 'Damat Ferit'.

Your (...........) finished the course.

Every (............) teacher has a nickname like you do.

I have been teaching for 25 years and labored (.............).

You have to attend $(\ldots \ldots \ldots \ldots)$ on time.

3.5.2 My Father and My Son (2005)

Appropriateness of using the film as a foreign language for teaching Turkish

It is one of the films that can be used in Turkish language structure and culture teaching in the teaching of Turkish as a foreign language with its content about the influence of 1980 coup by our dialogue with the elements reflecting Turkish culture.

Theme

He is devoted to journalism education in the university from the farm in Aegean. However, his father, Hussein, wants him to read the agriculture engineering and take control of the farm's administration. Loyal is more actively involved in politics than in university years. His father, Hüseyin, who learned this, rejects his son for adoption. Sadik, who has been involved in many political events in the 70s, is facing more difficult days. The couple, who ran out on the 12 th of September in the early morning hours with the birth of their wife, cannot find a car to go to the hospital because the military coup is taking place in the country. Sadık's wife loses her life during childbirth, but the little Deniz is alive. Sadık, who is tortured and tortured after being imprisoned, finds no other way than to take Deniz to the farm in the Aegean, near his mother and his father, whom he has not spoken to when he realizes that his illness is deadly. To introduce her grandmother (Hümeyra) who uses a tractor and speaks with the radio, the bride Hanife (Binnur Kaya) who walks her bracelet to her throat, and a pure uncle (Yetkin Dikinciler), who are very interested in comics and her magical world, will be a very different experience for him. Sadık and Hussein's revenge with the past will cause quite troublesome developments. (https://en.wikipedia.org/wiki/My_Father_and_My_Son).

Players

Çetin Tekindor, Hümeyra Akbay, Fikret Kuşkan, Özge Özberk, Aegean Tanman, Yetkin Dikinciler, Erdal Tosun, Nergis Çorakçı, Mahmut Gökgöz, Halit Ergenç.

Activity of teaching a word related to Hababam class movie

The Name of the Activity: Matching the word and the meaning activity.

Instruction: A list of the words that are already in the stage prepared by the teacher is given. Students are asked to concentrate on the words and phrases on the vocabulary list given specifically on the stage to be shown to the students. A two minute scene from the film is shown. Then students are given a study paper to match their words and meanings. Finally, the answers of the students are checked and evaluated.

Application:

Scene to be watched: $63.00-65.00$

Worksheet Example:

Words Taking Meanings of The Words

Place on the Stage

Home (House)

Most of the population is engaged in trade, industry, service or management related activities, usually residential areas where there are no agricultural activities.

Home $\quad$ Come to an ignorant position, to be strange.

Village An interest or analogy is a term used in a different sense.

Homeland The power, luck, fluke, which is the root of some random events that can not be reasoned.

Calm Bring to mind something that is known and forgotten.

Become estranged Quiet, cheerful, seedy, silent.

City Place of residence, housing, households.

Figurative The whole territory, under the sovereignty of a state, is the country.

expression

Remember

The residential and other structures, which are distinguished from the city in terms of management status, social and economic features or population density, are usually located in agricultural areas and this is the most suitable settlement unit.

Chance A piece of land on which a people live, cultivated as a cult, motherland. 


\section{Conclusion and Discussion}

In today's world, technology is developing rapidly. There have been many interactions among individuals with this development. Thus individuals had to learn a second language. As a second language, Turkish emerges as a learned and taught language due to its being spoken in many parts of the world (Y1lmaz \& Y1ld1z, 2016).

Although teaching Turkish as a foreign language started to develop in the last 20-25 years, due to the increasing international position and power of Turkey, it is necessary to recognize Turkey, Turks, and therefore Turkish culture and communicate more effectively with Turks. The number of people who want to learn Turkish abroad is rapidly increasing. In order to meet this demand and to promote Turkey in international arena, the issue of teaching Turkish to foreigners should be meticulously addressed. Büyükikiz and Hasırc1 (2013) also have the following suggestions in teaching Turkish as a foreign language: The target group should be well-recognized and the materials should be prepared according to the target group. In the course materials prepared according to the target group, the basic vocabulary should be given as a whole in a way that is related to each other. While the word is determined, care must be taken to ensure that the words are prepared at three basic levels (basic), B (intermediate) and C (upper). All meanings of the words should be taken into consideration; the needs of the student must be taken into account.

Research has shown that the use of film in foreign language teaching is also influential in the development of vocabulary, as well as the fact that students are in other language skills. For example, in the study of Ellsworth (1992), it has been found that students who are particularly concerned about the use of subtitled videos communicate more comfortably on the target audience and develop vocabulary. In the study by Chai, Judy and Erlam, Rosemary (2008), the participants were divided into two groups, one group subtitled film was watched while the other group film was not watched. As a result of the study, it was determined that more words and phrases were known than the other group that did not follow the group watching the movie. In Sydorenko (2010)'s research, it has also been revealed that students can better understand the written and verbal forms of the target language by watching the subtitles.

The use of films in teaching foreign languages or teaching foreigners in foreign languages cannot be seen as a simple phenomenon in the form of films or watching students alone. In order to achieve this success, supporting film watching activities should be created by the teacher. Watching a movie without sponsor events can result in failure. However, when using the right method with the right film, movies will be an effective and fun way to improve the vocabulary of students. At this point, foreign language teachers have important tasks. The most important task of the teacher is to provide a good learning environment for the students to improve their speaking skills.

The use of films that contribute to many aspects of language teaching in language teaching is common in other countries. However, if we want to increase the quality of the Turkish language as a foreign language and to increase the student's success, to appeal to the various senses of the students, to get them closer to the everyday Turkic and to promote the thoughts and emotional worlds, values, histories and cultures of the Turks, we have to use Turkish films effectively and adequately (Şimşek, 2016).

\section{References}

Arslan, M., \& Adem, E. (2010). Effective use of visual and auditory tools in teaching Turkish with foreign language. Language Magazine, 147, 63-86.

Büyükikiz, K. K., \& Hasırc1, S. (2013). An assessment of word teaching in teaching Turkish as a foreign language. Mustafa Kemal University Journal of Social Sciences Institute, 10(21), 145-155.

Celce-Murcia, M., \& Rosensweig, F. (1979). Teaching vocabulary in the ESL classroom. In Celce-Murcia, M. \& McIntosh, L. (Eds.) Teaching English as a Second or Foreign Language. Rowley: Newbury house publishers.

Chai, J., \& Erlam, R. (2008). The effect and the influence of the use of video and captions on second language learning. New Zealand Studies in Applied Linguistics, 14(2), 25-44.

Demirel, Ö. (2007). Foreign language teaching (3rd edition). Ankara: Pegem Academy Publications.

Ellsworth, T. (1992). Integrating subtitled video into your teaching. English Teaching Forum.5.

Hababam Class (2016, December 15). In Turkish general application and information site Retrieved from https://www.turkcebilgi.com/hababam_s\%C4\%B1n\%C4\%B1f\%C4\%B1_(film)

Harji, M., Woods, P., \& Alavi, Z. (2010). The effect of viewing subtitled videos on vocabulary learning. Journal of College Teaching \& Learning, 7(9), 37-42. https://doi.org/10.19030/tlc.v7i9.146

Harmer J. (2001). The Practice of English language teaching. (Third Edition). Essex: Pearson education.

How to Teach Film-Related Vocabulary (2016, December 25). In English as a second language. Retrieved from http://www.eslteachersboard.com/cgi-bin/lessons/index.pl?read=4295 
Ilgizovna, A. L. (2015) Пожалуйста, не забудьте правильно оформить цитату: Асадуллина Л. И., Дусеев И. Р. Teaching vocabulary through films // Молодой ученый. -2015. -№11.-С. 1255-1258. Http://www.moluch.ru/archive/91/19845/

Kana, F., \& Keskin, D. (2014). Teaching Turkish as a foreign language. In A. Şahin (Ed.), Teaching Turkish as a Foreign Language (pp. 417-440). Ankara: Pegem Academy.

Karatay, H. (2007). Vocabulary teaching, Journal of Gazi Education Faculty, 27(1), 141-153.

King, J. (2002). Using DVD feature films in the EFL classroom. Computer Assisted Language Learning, 15(5), 509-523. https://doi.org/10.1076/call.15.5.509.13468

Korkmaz, Z (1992). Grammar terms glossary, Ankara: Turkish Language Institute Publications.

Language teaching with films. (2016, December 25). In University College of Northern Denmark. Retrieved from http://www.ucnorth.dk/Files/Filer/CFU/Fagene/engelsk/Penguin_Readers_Teachers_Guide_Film_TV.PDF

Lewis, M. (1993). The lexical approach: The state of ELT and a way forward. Hove, UK: Language Teaching Publications.

My father and my son (2016, November 20). In Wikipedia, the free encyclopedia. Retrieved from https://en.wikipedia.org/wiki/My_Father_and_My_Son

Nation, I.S.P. (1990) Teaching and learning vocabulary. Boston, Mass: Heinle \& Heinle Publishers.

Putra B. (2014). Learning vocabulary using english movie with subtitles. Humanis, 22(1). (http://ojs.Unud.ac.id/index.php/sastra/).

Rajasekaran, V. (2015). The effect of reading-based activities in enhancing vocabulary-an observational study, $M J A L$, $7(3)$.

Ruusunen, V. (2011). Using movies in EFL teaching: The point of view of teachers (Unpublished master's thesis). University of Jyväskylä Department of Languages English, Finland.

Shirazi, R. R., Account, A., \& Simin, S. (2016). Effect of pedagogical movie English subtitles on EFL learner's vocanulary improvement. International Journal of Research Studies in Langage Learning, 5(2), 47-56 (http://www.consortiacademia.org/index.php/ijrsll/index).

Şimsek, M. R. (2016). Developing film-based teaching activities in foreign language teaching in Turkey: integrated skill approach. The Journal of Academic Social Science Studies, 47, 319-330.

Sydorenko, T. (2010). Modality of input and vocabulary acquisition. Language Learning and Technology, 14, 50-73.

Talavan, N. (2007). Learning vocabulary through authentic video and subtitles. Tesol-Spain newsletter, 31, 5-8.

Taşdemir, E., Bilkan, N., \& Can, H. (2004). Turkish instructional techniques. Izmir: Dilset Publications.

Turkish Language Association (2005). Turkish dictionary. Ankara: Turkish Language Institute Publications.

Wilkins, D. (1972). Linguistics in language teaching. London: Arnold.

Yıldız, U. F. (2013). Word and word teaching. In M. Durmuş \& A. Okur (Eds.), Handbook of teaching Turkish to foreigners (pp. 357-364). Ankara: Grafiker Publications.

Yilmaz, F., \& Yildiz, E. (2016). Attitudes and competences of the students of the Turkish education department on the teaching of the Turkish language teaching with foreigners, Turkish Language and Literature and History of Turkish Language, 11(19), 841-858. https://doi.org/10.7827/TurkishStudies.10046

Yüksel, D., \& Tanrıverdi B. (2009). Effects of watching video clip on vocabulary development of EFL learners. The Turkish Online Journal of Educational Technology, 8(2), 48-54.

Zarei, A. A. (2009). The effect of bimodal, standard and reversed subtitling on 12 vocabulary recognition and recall. Pazhuhesh-e Zabanha-ye Khareji, 49, 65-84.

\section{Copyrights}

Copyright for this article is retained by the author(s), with first publication rights granted to the journal.

This is an open-access article distributed under the terms and conditions of the Creative Commons Attribution license which permits unrestricted use, distribution, and reproduction in any medium, provided the original work is properly cited. 